\title{
EFFECT OF TRAFFIC INTENSITIES OF A DIRECTIONAL FELLER AND SKIDDER ON THE COMPACTION OF A BRUNO NITISOL
}

Tamara Izabel de Andrade Payá ${ }^{\odot}$, Eduardo da Silva Lopes $^{3 *}{ }^{\circ}$, Karina Maria Vieira Cavalieri-Polizeli ${ }^{4} \mathbb{C}^{-}$ Henrique Soares Koehler ${ }^{5}$, Marcelo Marques Lopes Muller ${ }^{\circ}$ and Matheus Kaminski Candido da Silva $^{7} \odot$

\footnotetext{
${ }^{1}$ Received on 07.05.2017 accepted for publication on 17.06.2019.

${ }^{2}$ Universidade Estadual do Centro-Oeste, Programa de Pós-Graduação em Ciências Florestais, Irati, PR- Brasil . E-mail: <tamarapaya@yahoo.com.br>.

${ }^{3}$ Universidade Estadual do Centro-Oeste, Departamento de Engenharia Florestal, Irati, PR- Brasil. E-mail: <eslopes@unicentro.br>.

${ }^{4}$ Universidade Federal do Paraná, Departamento de Solos, Curitiba, PR- Brasil.E-mail: <karina.cavalieri@ufpr.br>.

${ }^{5}$ Universidade Federal do Paraná, Departamento de Fitotecnia, Curitiba, PR- Brasil. E-mail: < koehler@ufpr.br>.

${ }^{6}$ Universidade Estadual do Centro-Oeste, Departamento de Agronomia, Guarapuava, PR- Brasil. E-mail: <mmuller@unicentro.br>.

${ }^{7}$ Universidade Estadual do Centro-Oeste, Programa de Pós-Graduação em Engenharia Florestal, Irati, PR- Brasil. E-mail:

<matheuskcs@gmail.com>.

*Corresponding author.
}

\begin{abstract}
This study evaluated the compaction of a Bruno Nitisol caused by traffic intensities by a directional feller and skidder used to wood harvesting in a Pinus taeda stand. Data were collected at a forest company located in Parana State, Brazil. Samples were performed using an installation of four blocks $(30 \times 15 \mathrm{~m})$ with subdivided plots and the treatments included a combination of five traffic simulations of directional feller and skidder machines, with the simulations performed in the plots at four soil depths, referred to as subplots. Compaction was evaluated by soil density, total porosity, microporosity, and macroporosity. The data were submitted to analysis of variance and the means were compared with the Tukey test at a 5\% level of significance. Linear regression equations were also adjusted to represent the relation between traffic intensity, depth, and the variable of interest. The results showed that machine traffic caused higher compaction of the superficial soil layers, resulting in a $14.6 \%$ increase in soil density compared to the soil subjected to no machine traffic. The increase in traffic intensity of the skidder tractor reduced macroporosity by $62.5 \%$ and $53.8 \%$ at depths of $0-10$ and $10-20 \mathrm{~cm}$, respectively. Dragging of the logs by the skidder tractor increased soil compaction due to the several trips by the machine in a single line.
\end{abstract}

Keywords: Mechanized harvest; Forest soils; Physical attributes.

\section{EFEITO DE DIFERENTES INTENSIDADES DE TRÁFEGO DO FELLER DIRECIONAL E SKIDDER NA COMPACTAÇÃO DE UM NITOSSOLO BRUNO}

RESUMO - Esta pesquisa avaliou a compactação de um Nitossolo Bruno causada por diferentes intensidades de tráfego do feller direcional e skidder na colheita de madeira em um povoamento de Pinus taeda. Os dados foram coletados em uma empresa florestal localizada no estado do Paraná, Brasil. O procedimento de amostragem foi realizado pela instalação de quatro blocos $(30 \mathrm{~m} \times 15 \mathrm{~m})$ com parcelas subdivididas e os tratamentos representados pela combinação de cinco simulações de tráfego das máquinas feller direcional e skidder, aplicadas nas parcelas em quatro profundidades do solo e em subparcelas. A compactação foi avaliada pela densidade do solo, porosidade total, microporosidade e macroporosidade. Os dados foram submetidos à análise de variância e as médias comparadas pelo teste de Tukey ao nivel de 5\% de significância. Foram ainda ajustadas equações de regressão linear para representar a relação entre a intensidade do tráfego, profundidade e a variável considerada. Os resultados mostraram que tráfego das máquinas provocou maior compactação nas camadas superficiais do solo, resultando em incrementos na densidade do solo na ordem de $14,6 \%$ em relação à condição sem tráfego de máquinas. O aumento da intensidade de tráfego do skidder contribuiu com a redução de 62,5\% e 53,8\% nos valores de macroporosidade para as profundidades de 0-10 e 10-20 cm, respectivamente. A atividade de arraste das árvores com o trator skidder contribuiu para o aumento da compactação do solo, acarretada pelas diversas passadas da máquina em uma única linha.

Palavras-Chave: Colheita mecanizada; Solos florestais; Atributos fisicos.

Silf $(c)$ EY

Revista Árvore 2019;43(1):e430111 http://dx.doi.org/10.1590/1806-90882019000100011 


\section{INTRODUCTION}

Intensified mechanization in wood-harvesting operations has contributed to increase productivity, improve quality and safety of operations, as well as to reduce the production costs (Machado et al., 2014). However, the use of machines with higher load capacity has negative impacts on the soil, and affects the capacity and sustainability of forest production.

Two typical systems are used by most companies during wood harvesting: "full tree" and "cut to length". The first is characterized by the use of a feller buncher or directional feller, skidder, and harvester processor, which normally compact the soil. This is caused by the absence of residual biomass resulting from wood processing; however, it has a lower operating cost. The second is composed of a harvester and forwarder, which has a lower impact on the soil due to low biomass exports; however, it has higher operating costs (Lopes et al., 2015).

Compaction involves rearranging soil particles and aggregates, which means that the shape and size of soil particles are altered under continuous pressure, resulting in increased soil density and decreased porous space (Hamza and Anderson, 2005). Hillel (1998) noted that soil exposed to pressure tends to compress, thus increasing its density. This happens because of the reduced porosity through the partial expulsion of air and/or water, resulting in soil compaction.

Despite increases in the use of machines with extra-wide wheels, excessive traffic of woodharvesting machines continues to be a concern, and is one of the main causes of soil compaction. For Dedecek and Gava (2005), this makes it difficult for water to escape and for the plants to grow. In addition, it considerably affects crop production and influences environmental quality due to susceptibility to erosion.

The intensity of machine traffic determines the level of soil compaction in terms of depth due to the several trips made by the machines over a single line during wood-harvesting, increasing the pressure applied onto the soil, which is often larger in relation to their load-bearing capacity (Dias Júnior, 2000). Conversely, each soil reacts differently when pressure is applied onto its surface by machine traffic for different durations, with the first trips causing more damage to the soil (Ampoorter et al., 2010; Szymczak et al., 2014).
Seixas and Souza (2007) studied the effect of compaction as a function of traffic frequency on a soil with sandy texture and reported that $80 \%$ of the increase in soil density occurred after 20 trips by an agricultural tractor coupled to a wood-loaded cart. Lopes et al. (2006) studied the effect of wood drag with a clambunk forest machine over different routes, and observed that the highest soil density occurred when the machine traveled once or twice loaded.

Zenner and Berger (2008) and Alakukku et al. (2003) noted that controlled machine traffic is an alternative way of reducing soil compaction that is observed in a smaller possible area, especially under situations of high soil moisture content. Fenner (2014) reported that reducing the pressure exerted by the machines on the soil by carrying smaller loads, increasing the number of wheels, increasing the tire width, and through the use of a suitable suspension system significantly reduced compaction.

Furthermore, the possibility of reduced forest production due to the degraded physical quality of soil in response to increased traffic by wood-harvesting machines has led companies in the forest sector to show interest in the identification, quantification, and resolution of soil compaction problems.

The objective of this paper was to evaluate the effect of different traffic intensities of a directional feller and skidder used to harvest a Pinus taeda stand on a Bruno Nitisol, and to obtain information that can contribute to operations management and the sustainability of forest production.

\section{MATERIAL AND METHODS}

This study was conducted in the woodharvesting operational areas of a forest company located in the Midwest region, Parana State, Brazil, at the geographic coordinates of $25^{\circ} 10^{\prime} 26^{\prime \prime} \mathrm{S}$ and $51^{\circ} 45^{\prime} 41^{\prime \prime} \mathrm{W}$, containing a 12-year-old Pinus taeda stand with a spacing of $3 \times 2 \mathrm{~m}$ and an average volume of $377.73 \mathrm{~m}^{3} \mathrm{ha}^{-1}$.

The climate of the region is temperate $(\mathrm{Cfb})$ according to the Köppen classification, with an average temperature of $19.7^{\circ} \mathrm{C}$, average annual precipitation between 1,800 and 2,000 $\mathrm{mm}$ and an altitude of 1,100 $\mathrm{m}$ (Iapar, 2000). The soil is classified as Bruno Nitisol, typically clayey, with average contents of $6.5 \%$ coarse sand, $3.9 \%$ fine sand, $30.7 \%$ silt, and $58.9 \%$ clay, an

Revista Árvore 2019;43(1):e430111 
average organic carbon content (C-org) of $25.6 \mathrm{~g} \mathrm{dm}^{-3}$ and average soil moisture of $0.52,0.51$ and $0.51 \mathrm{Uv}$ $\left(\mathrm{m}^{3} \cdot \mathrm{m}^{-3}\right)$ at depths of $0-10,10-20 ; 20-40$, and 40-60 $\mathrm{cm}$, respectively. The granulometry was analyzed by the pipette method according to the methodology proposed by Embrapa (1997), whereas the organic carbon contents were determined by the WalkleyBlack method (Raij et al., 2001).

The wood-harvesting system used by the company was full tree. A Caterpillar $320 \mathrm{D}$ directional feller (DF) was studied with an engine power of 157 HP, crawler wheels, and an operating weight of 26.9 t. It was equipped with a Satco 420 head and was responsible for the individual felling and stacking the trees in bundles inside the field. Additionally, a Catterpillar 545 skidder (SK) was studied with an engine power of $219 \mathrm{HP}$, tire wheels with $4 \times 4$ traction, and an operational weight of 19.19 t. It was responsible for dragging the trees from the interior of the field to the edge for further processing and transporting the wood.

Samples were collected with the help of a digger, sledgehammer, and piercer (Sonda Terra, Brazil) to determine soil density; the samples collected using the piercer were non-deformed. Volumetric rings $\left(95 \mathrm{~cm}^{3}\right)$ were inserted in the center of the $0-10$; $10-20 ; 20-40$, and 40-60 cm depths until filled. Soil density was determined by the relationship between dry soil weight (Wds) in an oven at $105^{\circ} \mathrm{C}$ for $48 \mathrm{~h}$ and the volumetric ring volume $(\mathrm{V})$ was determined according to the methodology proposed by Blake and Hartge (1986), using equations 1:

$$
S D=\frac{W d s}{V}
$$

Where: $\mathrm{SD}=$ soil density $\left(\mathrm{Mg} \mathrm{m}^{-3}\right), \mathrm{Wds}=$ dry soil weight at $105^{\circ} \mathrm{C}(\mathrm{Mg})$, and $\mathrm{V}=$ volume of soil contained in the ring $\left(\mathrm{m}^{-3}\right)$.

The samples were protected in the lower part of the cylinder by a disk of permeable cloth to determine total porosity, microporosity, and macroporosity, and were then transported to the laboratory in a tray with water, where they remained for a few days before saturation was calculated.

Next, the samples were removed from the water and weighed to obtain the weight of the soil saturated with water (Wssw). Samples were then transferred to a tension table with the potential corresponding to a $60 \mathrm{~cm}$ water column, where they remained for $48 \mathrm{~h}$. Finally, the samples were weighed again after being subjected to tension from the $60 \mathrm{~cm}$ water column (Wst), and then placed in an oven at $105^{\circ} \mathrm{C}$, where they remained for $48 \mathrm{~h}$. Samples were then weighed again to determine the dry soil weight (Wds).

Once the soil weight and density were determined, the total porosity, microporosity, and macroporosity were obtained by equations 2,3 , and 4 .

$$
\begin{aligned}
& T P=\frac{W s s w-W d s}{W d s} x S D \\
& M I=\frac{W s t-W d s}{W d s} x S D \\
& M A=T P-M I
\end{aligned}
$$

Where: $\mathrm{TP}=$ total porosity $\left(\mathrm{m}^{3} \mathrm{~m}^{-3}\right)$, Wssw $=$ weight of the soil saturated with water $(\mathrm{g}), \mathrm{Wds}=$ weight of oven-dried soil at $105^{\circ} \mathrm{C}(\mathrm{g}), \mathrm{SD}=$ soil density $\left(\mathrm{Mg} \mathrm{m}^{-3}\right)$, $\mathrm{MI}=$ microporosity $\left(\mathrm{m}^{3} \mathrm{~m}^{-3}\right)$, Wst $=$ soil weight with tension from a $60-\mathrm{cm}$ water column (g); Wds = weight of oven-dried soil at $105^{\circ} \mathrm{C}(\mathrm{g}), \mathrm{SD}=$ soil density $\left(\mathrm{Mg} \mathrm{m}^{-3}\right), \mathrm{MA}=$ macroporosity $\left(\mathrm{m}^{3} \mathrm{~m}^{-3}\right)$.

A randomized block design with subdivided plots was used, in which five treatments with four replicates were tested. The treatments included a combination of five simulations of wood-harvesting machine traffic $(\mathrm{NT}, 1 \mathrm{FD}+1 \mathrm{SK}, 1 \mathrm{FD}+2 \mathrm{SK}, 1 \mathrm{FD}+4 \mathrm{SK}$ and $1 \mathrm{FD}+8 \mathrm{SK}$ ) which were applied to plots at depths of $0-10,10-20 ; 20-40$, and $40-60 \mathrm{~cm}$, referred to as subplots.

The results were submitted to analysis of variance, and treatment variances were initially evaluated for homogeneity by the Bartlett test. The effects of variables with homogeneous variance were tested by the F-test, and the means of the treatments were compared by the Tukey test when necessary at a $5 \%$ level of significance.

A linear regression equation was adjusted for each traffic simulation with the studied machines 
to represent the relationship between the traffic intensity and the variable of interest. Trend curves were presented for the four evaluated depths with the best-adjusted equation, as well as the coefficient of determination.

\section{RESULTS}

Table 1 shows the analysis of variance for the soil density $\left(\mathrm{Mg} \mathrm{m}^{-3}\right)$, total porosity $\left(\mathrm{m}^{3} \mathrm{~m}^{-3}\right)$, microporosity $\left(\mathrm{m}^{3} \mathrm{~m}^{-3}\right)$ and macroporosity $\left(\mathrm{m}^{3} \mathrm{~m}^{-3}\right)$, as well as the chi-squared values $\left(\chi^{2}\right)$ for the Bartlett test. All the analyzed variables presented variances for the homogeneous treatments, and did not require data transformation.

Interactions for soil density were found between DF/SK and traffic intensity with a significant difference $(p<0.05)$, indicating that their effects are not independent. Only the DF/SK factor was significant( $p$ $<0.01)$. The blocks presented significant differences, indicating that there were differences between the experimental units, as expected for this variable.

Average soil densities are presented in Figure 1. Notably, no significant differences between the SD means were found for the different intensities for the analysis of variance at depths of $0-10$ and $10-20 \mathrm{~cm}$, and were all higher with traffic than without traffic. SD did not differ at depths of 20-40 and 40-60 cm for any of the traffic intensities of the tested woodharvesting machines.

In the absence of traffic, the analysis of variance revealed that the soil density at depths of 20-40 and $40-60 \mathrm{~cm}$ did not differ statistically, and this was also observed under the other studied traffic conditions and depths. The soil density pattern at depths of $0-10,10-20$, and $20-40 \mathrm{~cm}$ are represented by a second-degree polynomial equation, explaining that $89 \%, 88 \%$, and $89 \%$ of the SD was dependent on the different evaluated traffic intensities (Figure 1). The behavioral trend observed for SD at a depth of 40$60 \mathrm{~cm}$ is represented by a line equation, explaining $93 \%$ of the density behavior in relation to the traffic conditions.

Total porosity results (Table 1) showed that there were interactions between DF/SK and soil depth, as well as the main factors which were not significant $(p>0.05)$ alone. This indicates that their effects are independent and do not differ from each other. The blocks exhibited a significant difference, indicating that there were differences between the experimental units for this variable.

Average total porosities are presented in Figure 2. These values were not influenced by the traffic intensity of the wood-harvesting machines, or the evaluated soil depths. Soil porosity at depths of $0-10$, 10-20, and 40-60 cm exhibited behavior which could be represented by a second-degree polynomial equation (Figure 2), explaining that $87 \%, 99 \%$, and $41 \%$ of the results are related to the different traffic conditions. The TP pattern at the $20-40-\mathrm{cm}$ depth is represented by a line equation, which explains $72 \%$ of the variable's behavior.

Mean microporosity is presented in Figure 3. The results indicated that only the soil depth factor was significant $(p<0.01)$. The interaction between traffic intensity and soil depth was not significant,

Table 1 - Analyses of variance for soil density $\left(\mathrm{Mg} \mathrm{m}^{-3}\right)$, total porosity $\left(\mathrm{m}^{3} \mathrm{~m}^{-3}\right)$, microporosity $\left(\mathrm{m}^{3} \mathrm{~m}^{-3}\right)$, and macroporosity $\left(\mathrm{m}^{3} \mathrm{~m}^{-3}\right)$.

Tabela 1 - Análise de variancia para a densidade do solo (Mg $m-3)$, porosidade total $\left(m^{3} m-3\right)$, microporosidade $\left(m^{3} m-3\right) e$ macroporosidade $\left(m^{3} \mathrm{~m}-3\right)$.

\begin{tabular}{lccccc}
\hline Sources of variation & D.F. & \multicolumn{3}{c}{ Mean square } \\
\cline { 2 - 6 } & & SD & TP & MI & MA \\
\hline Blocks & 3 & $0.03457^{* *}$ & $0.00480^{*}$ & $0.00258^{\text {ns }}$ & $0.00082^{\text {ns }}$ \\
DF/SK & 4 & $0.02529^{* *}$ & $0.00179^{\text {ns }}$ & $0.00399^{\text {ns }}$ & $0.00689^{* *}$ \\
Error (a) & 12 & 0.00394 & 0.00127 & 0.00214 & 0.00078 \\
Depths & 3 & $0.00135^{\text {ns }}$ & $0.00064^{\text {ns }}$ & $0.00518^{* *}$ & $0.00260^{* *}$ \\
Interaction DF/SK $\times$ depths & 12 & $0.00321^{*}$ & $0.00042^{\text {ns }}$ & $0.00123^{\text {ns }}$ & $0.00124^{* *}$ \\
Error (b) & 45 & 0.00136 & 0.00052 & 0.00063 & 0.00037 \\
Coefficient of variation (\%) & $5.7 / 3.3$ & $5.4 / 3.5$ & $8.0 / 4.4$ & $33.8 / 23.4$ & \\
Chi-squared $(\square 2)$ & $17.05 \mathrm{~ns}$ & $16.98^{\text {ns }}$ & $11.12^{\text {ns }}$ & $17.76^{\text {ns }}$ & \\
\hline
\end{tabular}

ns $=$ not significant; $*=$ significant at $5 \% ; * *=$ significant at $1 \%$

Revista Árvore 2019;43(1):e430111 

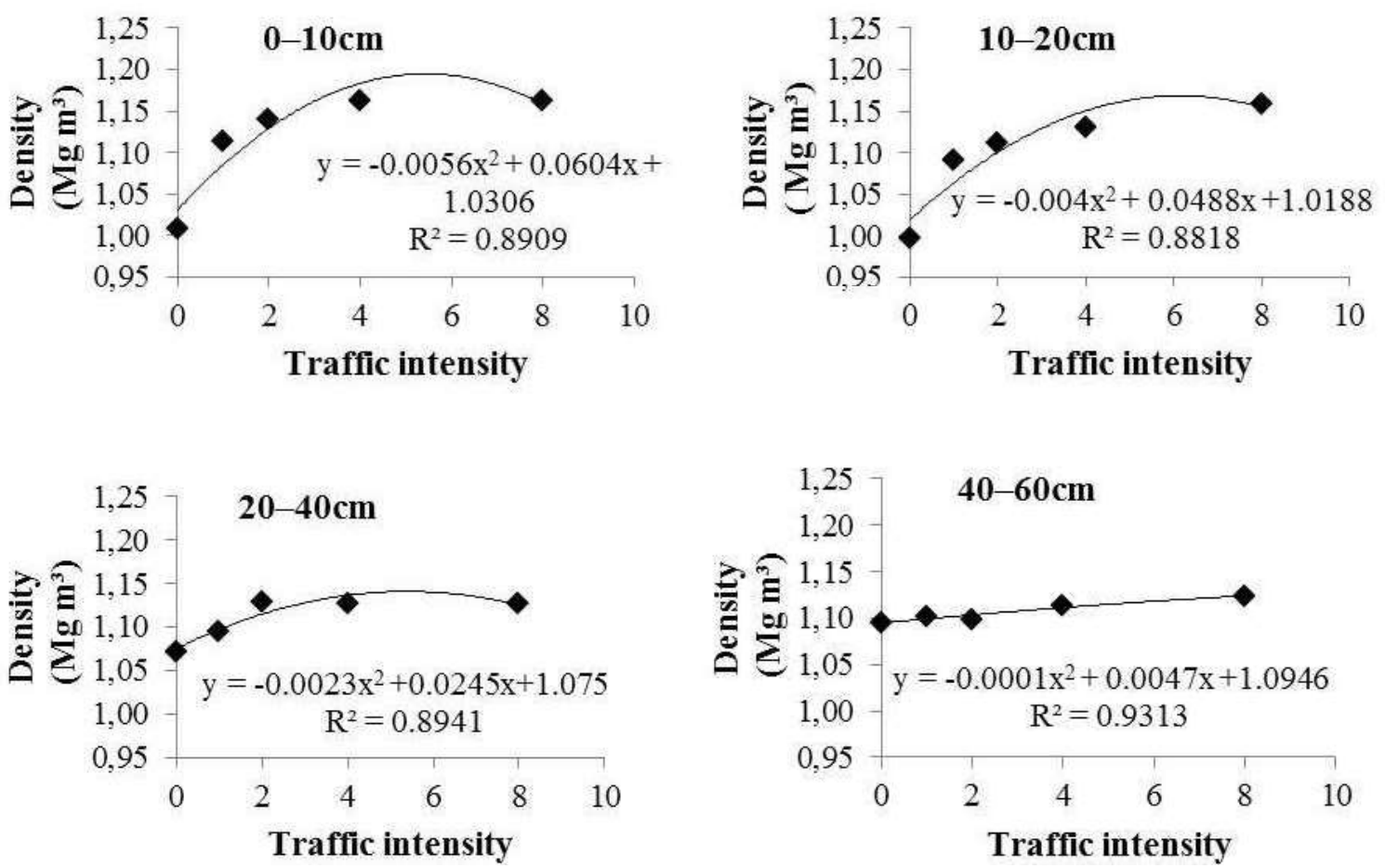

Figure 1 - Adjusted regression equations and determination coefficients $\left(\mathrm{R}^{2}\right)$ for the relationship between traffic intensity and soil density (Mg m-3) at depths of 0-10,10-20, 20-30, and 40-60 cm.

Figura 1 - Equações de regressão ajustadas e coefi cientes de determinação $\left(R^{2}\right)$ para a relação entre a intensidade de tráfego e a porosidade total $\left(\mathrm{m}^{3} \mathrm{~m}-3\right)$ nas profundidades $0-10 \mathrm{~cm}, 10-20 \mathrm{~cm}, 20-30 \mathrm{~cm}$ e $40-60 \mathrm{~cm}$.

indicating independence of these factors. The mean comparison test showed that the MI was superior and statistically different at a depth of 40-60 $\mathrm{cm}$ in relation to the other tested depths; therefore, there were no significant differences between the studied traffic intensities.

Soil microporosity at depths of $0-10,10-20$, 20-30 and 40-60 cm followed a pattern which can be represented by a second-degree polynomial equation (Figure 3), explaining that $68 \%, 79 \%, 32 \%$, and $16 \%$ of the MI values, respectively, are correlated with the different traffic intensities of the wood-harvesting machines.

Analysis of variance for soil macroporosity revealed that the interaction between $\mathrm{DF} / \mathrm{SK}$ and soil depth was statistically significant $(\mathrm{p}<0.01)$, indicating that their effects are not independent. The traffic intensity and soil depth factors also showed significant differences when evaluated alone $(\mathrm{p}<$ $0.01)$.
Average MA values are presented in Figure 4, and the MA value for the control at a depth of $0-10 \mathrm{~cm}$ presented results which were higher and statistically different from the other traffic conditions. The $1 \mathrm{DF}+$ $1 \mathrm{SK}$ and $1 \mathrm{DF}+2 \mathrm{SK}$ control and traffic conditions at the $10-20 \mathrm{~cm}$ depth were equal and superior to the other studied situations, whereas there were no differences between the tested traffic conditions at depths of 20-40 and 40-60 cm.

In the no-traffic condition there was no significant difference in soil macroporosity at depths of 0-10 and 10-20 cm, whereas the MA did not differ at depths of $10-20,10-20$, and $40-60 \mathrm{~cm}$ in the $1 \mathrm{DF}+1 \mathrm{SK}$ traffic condition. No significant differences were found for the other traffic intensities of $1 \mathrm{DF}+2 \mathrm{SK}$, $1 \mathrm{DF}+4 \mathrm{SK}$ and $1 \mathrm{DF}+8 \mathrm{SK}$ at any studied depth.

The soil macroporosity pattern for all tested depths could be represented by a second-degree polynomial equation, which explained that $88 \%$, $90 \%, 39 \%$, and $48 \%$ of the MA values were related to the different evaluated traffic conditions. 

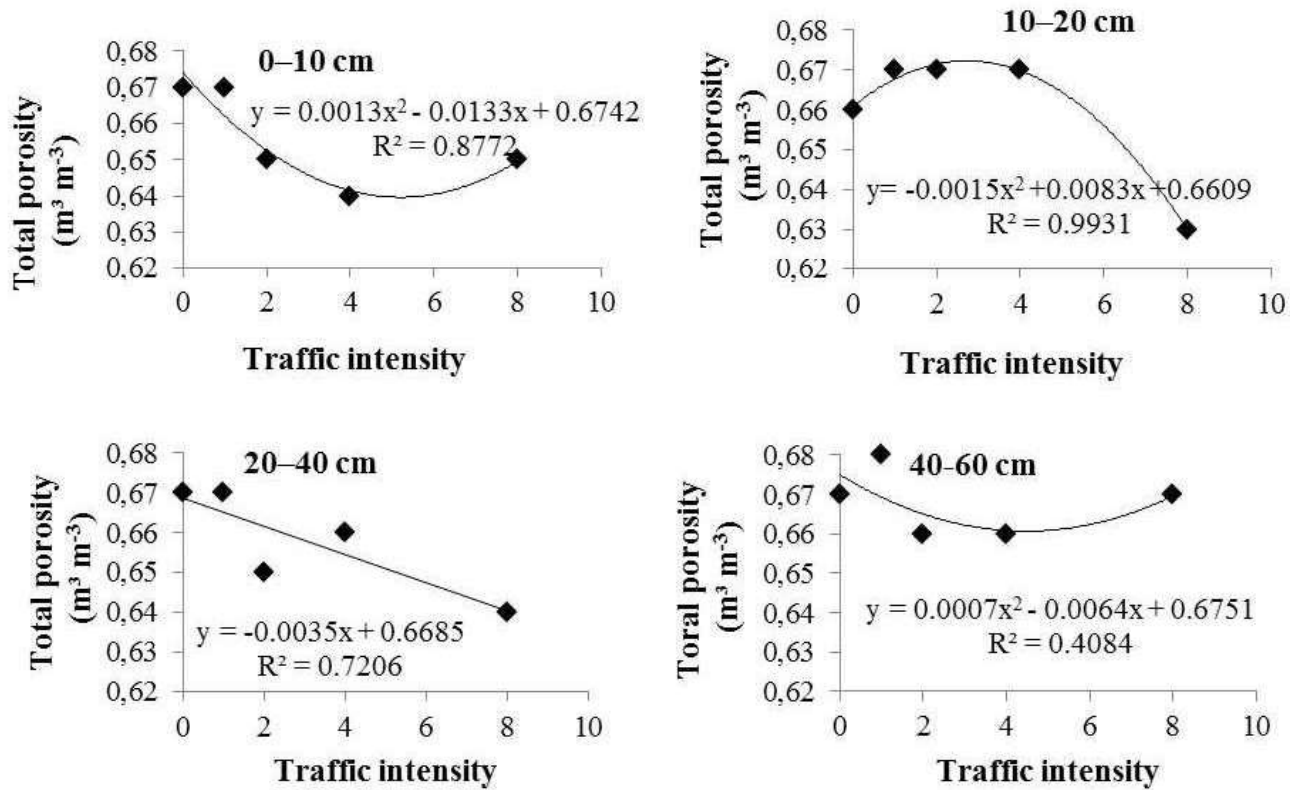

Figure 2 - Adjusted regression equations and coefficients of determination $\left(\mathrm{R}^{2}\right)$ for the relationship between traffic intensity and total porosity $\left(\mathrm{m}^{3} \mathrm{~m}^{-3}\right)$ at depths of $0-10,10-20,20-30$, and $40-60 \mathrm{~cm}$.

Figura 2 - Equações de regressão ajustadas e coeficientes de determinação $\left(R^{2}\right)$ para a relação entre a intensidade de tráfego e a porosidade total $\left(\mathrm{m}^{3} \mathrm{~m}^{-3}\right)$ nas profundidades $0-10 \mathrm{~cm}, 10-20 \mathrm{~cm}, 20-30 \mathrm{~cm}$ e $40-60 \mathrm{~cm}$
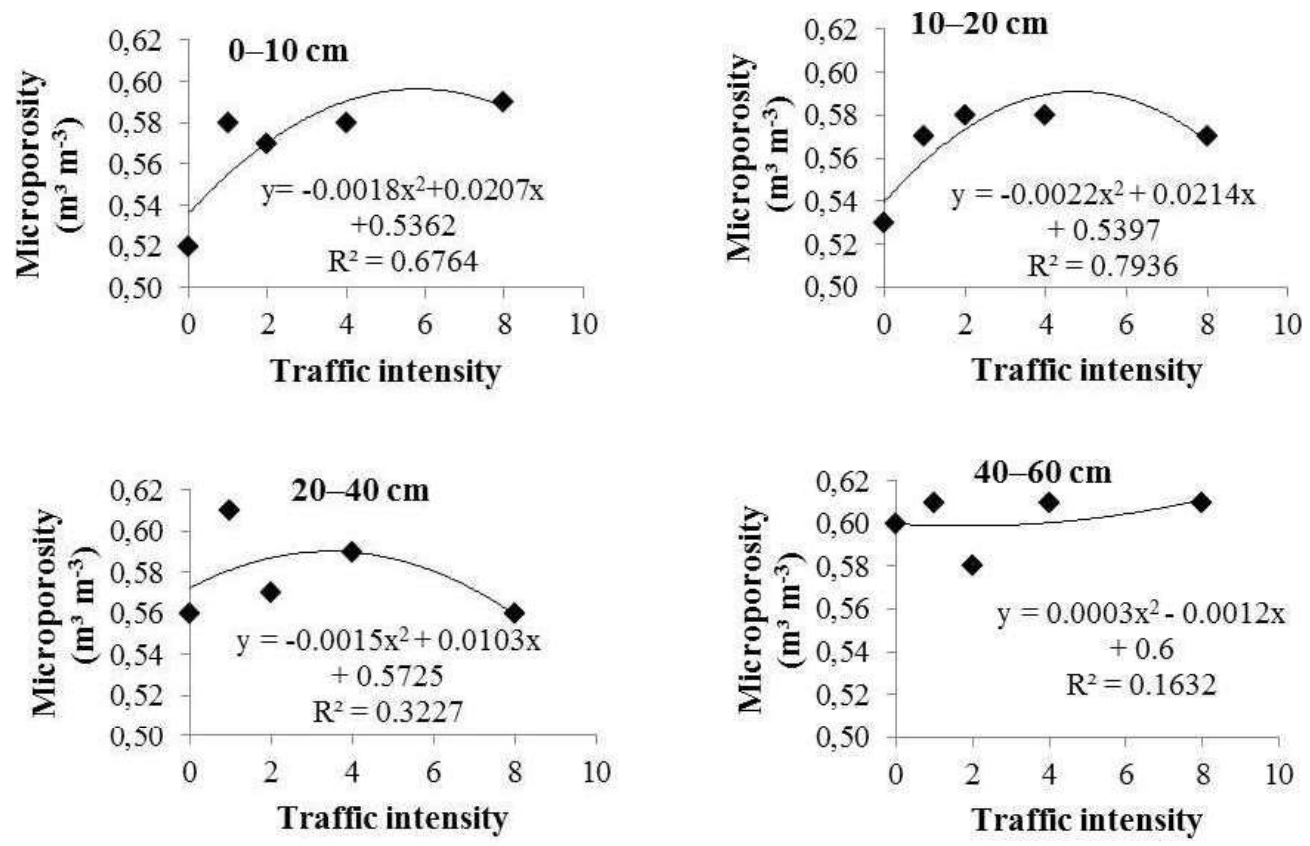

Figure 3 - Adjusted regression equations and coefficients of determination $\left(\mathrm{R}^{2}\right)$ for the relationship between traffic intensity and microporosity $\left(\mathrm{m}^{3} \mathrm{~m}^{-3}\right)$ at depths of $0-10,10-20,20-30$, and $40-60 \mathrm{~cm}$.

Figura 3 - Equações de regressão ajustadas e coeficientes de determinação $\left(R^{2}\right)$ para a relação entre a intensidade de tráfego e a microporosidade $\left(\mathrm{m}^{3} \mathrm{~m}^{-3}\right)$ nas profundidades $0-10 \mathrm{~cm}, 10-20 \mathrm{~cm}, 20-30 \mathrm{~cm}$ e $40-60 \mathrm{~cm}$.

Revista Árvore 2019;43(1):e430111 


\section{DISCUSSION}

Soil density under the no-traffic condition (Figure 1) increased with soil depth. Such observations were also reported by Lopes et al. (2015), who claimed that increasing density at greater soil depths is a natural trend due to the lower amount of organic matter when compared to the surface layers, and the lowest values of soil density observed in the superficial layers of the soil may be related to the biological activities and the natural process of wetting and drying, constituting factors which favor reduced soil compaction.

As the traffic intensity of the wood-harvesting machines increased in the $0-10 \mathrm{~cm}$ layer, the SD also increased, resulting in an increase of $13.8 \%$ in relation to the no-traffic area. Such results were also obtained at the $10-20 \mathrm{~cm}$ depth, where a gradual increase in SD was observed with the studied treatments, resulting in a $14.6 \%$ increase. Surface soil compactions caused by wood harvesting were also observed by Sampietro and Lopes (2011) who evaluated the feller buncher and skidder traffic on a Humic Cambisol. Higher SD values were obtained in the topsoil $(0-15 \mathrm{~cm})$ in that study at the highest traffic intensities, with a $13.1 \%$ increase with traffic intensity of $1 \mathrm{FB}+15 \mathrm{SD}$ (one
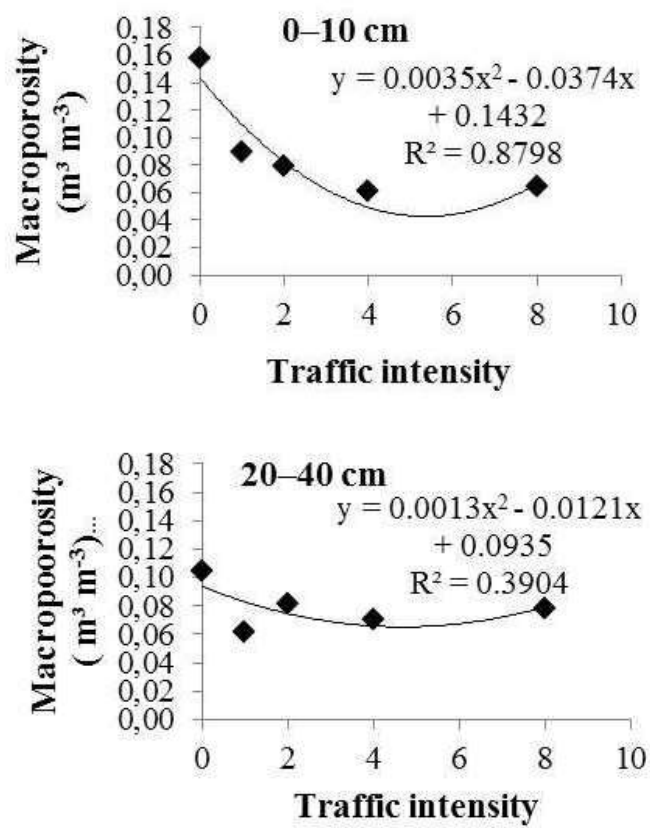

trip by the feller buncher +15 trips by the skidder) in relation to the condition without traffic (ST).

Regression analysis of soil density revealed a positive relationship between the studied factors. The interaction between traffic intensity and the SD at depths of $0-10,10-20$, and 20-40 cm stabilized before the eighth trip by the skidder, showing that the soil had already reached its maximum density, regardless of the number of subsequent trips. The soil did not suffer further changes at $1 \mathrm{DF}+8 \mathrm{SK}$, and this did not occur in the 40-60 cm layer, which presented a linear relationship, indicating that the higher the intensity of the machine traffic, the greater the soil density. Pezzoni Filho et al. (2014) also observed that the increasing number of skidder tractor passes over a Hapless Cambisol increased the soil density up to the fifth pass by $16.2 \%$ compared with the no-traffic condition.

Although the results obtained for total porosity were not significant, a strong relationship was observed between total porosity and soil density. When checking the microporosity values at all evaluated depths (Figure 3), it is noted that as the number of machine trips increased, the MI values increased,
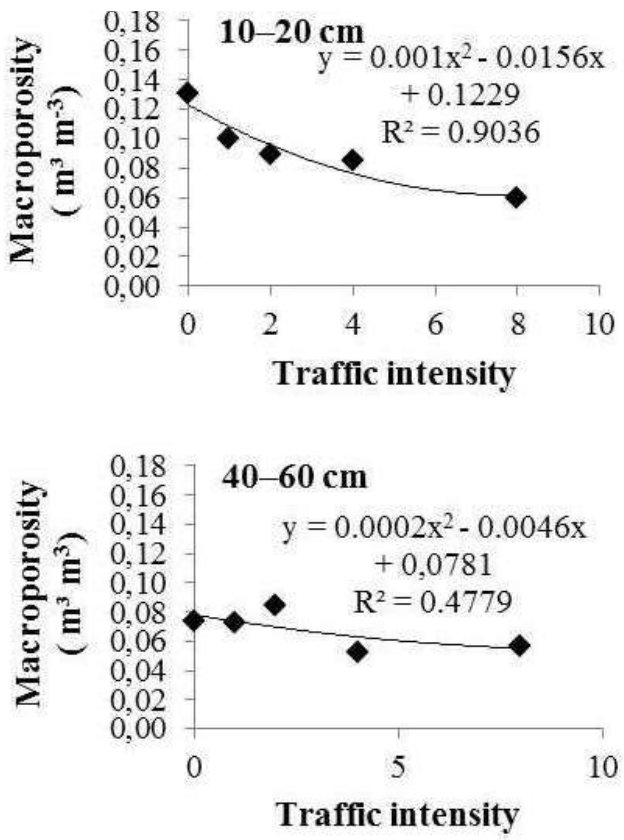

Figure 4 - Adjusted regression equations and coefficients of determination $\left(\mathrm{R}^{2}\right)$ for the relationship between traffic intensity and macroporosity $\left(\mathrm{m}^{3} \mathrm{~m}^{-3}\right)$ at depths of $0-10,10-20,20-30$, and $40-60 \mathrm{~cm}$.

Figura 4 - Equações de regressão ajustadas e coeficientes de determinação $\left(R^{2}\right)$ para a relação entre a intensidade de tráfego e a macroporosidade $\left(\mathrm{m}^{3} \mathrm{~m}^{-3}\right)$ nas profundidades $0-10 \mathrm{~cm}, 10-20 \mathrm{~cm}, 20-30 \mathrm{~cm}$ e $40-60 \mathrm{~cm}$. 
with the first trip causing the greatest changes in soil microporosity. Studies by Lacey and Ryan (2000) and Startsev and McNabb (2000) reported that most soil compaction occurs after the first trip by woodharvesting machines.

The increase in microporosity at the studied depths was due to the soil being exposed to different pressures exerted by the machines, causing the macropores to be compressed and rearranged, and subsequently transformed into micropores. Therefore, there tends to be a larger number of micropores present in areas of intense machine traffic due to the detriment of macropores. This reduction in pore size makes it difficult for water to infiltrate the soil, making it more susceptible to surface runoff, and favoring soil ridge and erosion formation.

Microporosity regression analysis (Figure 3) revealed that the $40-60 \mathrm{~cm}$ layer exhibited a different pattern than the other variables, with the depth being less affected by the machine traffic, but the higher amount of micropores is explained by the fact that this layer presents a very clayey texture.

For the macroporosity variable, the evaluated treatments presented low values along the soil depths (Figure 4). According to Reichert et al. (2007), MA values below $0.10 \mathrm{~m}^{3} \mathrm{~m}^{-3}$ are considered critical for plant development and growth. Thus, the MA values obtained in this study with machine traffic were lower than those presented by other authors, thus confirming that soil compaction occurs.

The superficial soil layers at $0-10$ and $10-20 \mathrm{~cm}$ were the most affected by the machine traffic which resulted in macroporosity values that were reduced by $62.50 \%$ and $53.84 \%$ in the respective soil layers. Frey et al. (2009) also found marked decreases in macroporosity with values ranging from 60 to $53 \%$ in several studied soils. Szymczak et al. (2014) reported that the macroporosity in the $0-5$ and 5-10 $\mathrm{cm}$ layers following wood-harvesting operations was compacted, with reductions between $60 \%$ and $50 \%$, respectively, in relation to the initial soil conditions.

Depths of 20-40 and 40-60 cm were less affected by the machine traffic in relation to the superficial layers, which presented low values of macroporosity at the baseline. This is characteristic of the normal evaluated conditions, because this soil presents a clayey texture.
The depths of $20-40$ and $40-60 \mathrm{~cm}$ were less affected by the machine traffic in relation to the superficial layers, which presented low values of macroporosity at the baseline.

A decreased number of macropores contributes to reduced root development of plants because of the low aeration conditions of the soil. This hinders the diffusion and exit of $\mathrm{CO}_{2}$ and the entry of $\mathrm{O}_{2}$ into the soil (Giarola et al., 2007; Startsev and Mcnabb, 2009). Reduced soil aeration may limit some plant metabolic processes such as stomatal closure, which can cause plant wilting, xylem obstruction to water, root necrosis, and nutritional and hormonal interference of plants (Sojka, 1992; Queiroz-Voltan et al., 2000).

\section{CONCLUSION}

- The evaluated variables revealed a dependence on traffic intensity; as intensity increased with more machine traffic, the damage caused to the soil increased;

- The superficial layer of soil in the forest plantation was the most affected by the traffic of the wood-harvesting machines, showing that the sensitivity of this layer is independent of the different traffic intensities;

- The increase in machine traffic intensity led to greater changes in the physical attributes of the soil in relation to the no-traffic condition, with a higher effect in the superficial layers of the soil;

- Increases in soil macroporosity were considered critical to plant development, proving that compaction in the wood-harvesting area is caused by the traffic of the wood-harvesting machines; and

- Log dragging by the skidder contributed to increased soil compaction caused by the multiple trips made by the machine in a single traffic line when compared with the directional feller, which only does a single trip through the cutting area.

\section{ACKNOWLEDGMENTS}

The authors give thanks to the Coordination for the Improvement of Higher Education Personnel (CAPES) for the scholarship and to the forest company for the support during the study. 


\section{REFERENCES}

Ampoorter E, van Nevel L, De Vos B, Hermy M, Verheyen K. Assessing the effects of initial soil characteristics, machine mass and traffic intensity on forest soil compaction. Forest Ecology and Management. 2010;260:1664-76.

Alakukku L, Weisskopf P, Chamen WCT, Tijink FGJ, van der Linden JP, Sires S, et al. Prevention strategies for field traffic-induced subsoil compaction: a review. Part 1. Machine/soil interactions. Soil \& Tillage Research. 2003;73:145-60.

Blake GR, Hartge KH. Bulk density. In: Klute A, editor. Methods of soil analysis: Physical and mineralogical methods. Madison: American Society of Agronomy; 1986. Pt 1. p.363-75.

Dedecek RA, Gava JL. Influência da compactação do solo na profundidade da rebrota de eucalipto. Revista Árvore. 2005;29(3):383-90.

Dias Júnior MS. Compactação do solo. Tópicos em ciência do solo. 2000;9:54-94.

Empresa Brasileira de Pesquisa Agropecuária Embrapa. Centro Nacional de Pesquisa de Solos. Manual de métodos de análise de solo. Rio de Janeiro: 1997.

Fenner PT. Compactação do solo. In: Machado CC. Colheita florestal. $3^{\circ}$.ed. Viçosa, MG: UFV; 2014. p.426-47.

Frey B, Kremer J, Rüdt A, Sciacca S, Matthies D, Lüscher P. Compaction of forest soils with heavy logging machinery affects soil bacterial community structure. European Journal of Soil Biology. 2009; 45:312-20

Giarola NFB, Tormena CA, Dutra AC. Degradação física de um Latossolo Vermelho utilizado para a produção intensiva de forragem. Revista Brasileira de Ciência do Solo. 2007;31(5):863-73.

Hamza MA, Anderson WK. Soil compaction in cropping systems: A review of the nature, causes and possible solutions. Soil \& Tillage Research. 2005;82:121-45.

Hillel D. Flow of water in unsaturated soil. In: Hillel D. Environmental soil physics. New York: Academic
Press; 1998. p.203-41.

Instituto Agronômico do Paraná - Iapar. Cartas Climáticas do Paraná [cd rom]. Londrina: 2000.

Lacey ST, Ryan PJ. Cumulative management impacts on soil physical properties and early growth of Pinus radiata. Forest Ecology and Management. 2000;138:321-33

Lopes ES, Oliveira D, Rodrigues CK, Drinko CH. Compactação de um Solo Submetido ao Tráfego do Harvester e do Forwarder na colheita de madeira. Floram. 2015;22(2):223-30.

Lopes SE, Fernandes HC, Machado CC, Rinald IPCN, Silveira JCM. Compactação de um Latossolo submetido ao tráfego do "Clambunk". Scientia Florestalis. 2006;72:23-8.

Machado CC, Silva EN, Pereira RS, Castro GP. O setor florestal brasileiro e a colheita florestal. In: Machado CC. Colheita florestal. $3^{\mathrm{a}}$ ed. Viçosa, MG: UFV; 2014. p.15-45.

Pezzoni Filho JC, Fenner PT, Lanças KP, Pezzoni D, Moraes WB, Chagas HA, et al. Compactação de um Cambissolo Háplico causada pela extração florestal com trator Skidder. Cerne. 2014;20(2):199-208.

Queiroz-Voltan RB, Nogueira SSS, Miranda MAC. Aspectos da estrutura da raiz e do desenvolvimento de plantas de soja em solos compactados. Pesquisa Agropecuária Brasileira. 2000;35(5):929-38

Raij B van, Andrade JC, Cantarella H, Quaggio JA. Análise para avaliação da fertilidade de solos tropicais. Campinas: Instituto Agronômico; 2001.

Reichert JM, Suzuki LEAS, Reinert DJ. Compactação do solo em sistemas agropecuários e florestais: identificação, efeitos, limites críticos e mitigação. Tópicos em Ciência do Solo. 2007;5:49-134.

Sampietro JA, Lopes ES. Compactação de um Cambissolo e Neossolo submetidos a diferentes intensidades de tráfego de Feller Buncher e Skidder. Scientia Forestalis. 2011;39(90):265-72.

Seixas F, Souza CR. Avaliação da compactação do solo, devido à frequência de tráfego, na produção de madeira de eucalipto. Revista Árvore. 2007;31(6):1047-52.

\section{Revista Árvore 2019;43(1):e430111}


Startsev AD, Mcnabb DH. Effects of skidding on forest soil infiltration in west-central Alberta. Canadian Journal of Soil Science. 2000;80(4):617-24.

Startsev AD, Mcnabb DH. Effects of compaction on aeration and morphology of boreal forest soils in Alberta, Canada. Canadian Journal of Soil Science. 2009;89(1):45-56.

Sojka RE. Stomatal closure in oxygen-stressed plants. Soil Science Society of America Journal. 1992;154(4):269-80.
Szymczak DA, Brun EJ, Reinert DJ, Frigotto T, Mazzalira CC, Dal'col -Lúcio A, et al. Compactação do solo causada por tratores florestais na colheita de Pinus taeda L. na região Sudoeste do Paraná. Revista Árvore. 2014;38(4):641-8.

Zenner EK, Berger AL. Influence of skidder traffic and canopy removal intensities on the ground flora in a clearcut-with-reserves northern hardwood stand in Minnesota - USA. Forest Ecology and Management. 2008;256(10):1785-9. 